\title{
Knowledge Data Mining in Population Structure and Transition of Economic Development Pattern
}

\author{
Jing-Yi Hou \\ School of Management \\ Hefei University of Technology \\ Hefei, P.R China \\ E-mail: wdhjy2003@sina.com
}

\author{
Wei-Zhong Fu, Cheng-Yan Han \\ School of Management \\ Hefei University of Technology \\ Hefei, P.R China \\ E-mail: weizhongfu@sina.com
}

\begin{abstract}
Transition of economic development pattern is a comprehensive harmony development process of population, resources, economy, environment and other systems, is an overall planning with people-oriented to harmonize urban and rural development, regional and national development, social economic development and opening up. It is helpful for knowledge data mining in harmony stage and trend to find harmony or disharmony reason between the two sub-systems, population structure system and economic development system. Based on the findings, suggestions on optimizing population structure are given to harmony with transition of economic development in China.
\end{abstract}

Keywords-population structure; coordination; transition of economic development pattern; harmony; knowledge data mining

\section{INTRODUCTION}

The Report of 17th National Congress of the Communist of China push forward strategic goal of accelerating the transition of the economic development pattern, to realize the continuance, equilibrium, sequence, harmony development of population, resource, environment, economy and other sub-systems in natural and social system. With sub-system of population structure and economic development as object, we do knowledge mining in harmony stage and trend between two sub-systems by solving 4 questions. First, what the integrated index of development is? Secondly, how to judge harmony level between population structure and economic developmentt with a decision model? Thirdly, what are key factors to influence the harmony development of two sub-systems?

\section{HARMONY DEVELOPMENT OF POPULATION STRUCTURE AND ECONOMIC DEVELOPMENT}

Harmony development of population structure and economic development is a comprehensive process of population and economy, is an overall planning with people-oriented to harmonize urban and rural development, regional and national development, social economic developmentt and opening up. Harmony is interrelation between factors of two systems. Due to the abundance data, we use the maturate principle components analysis to simplify indexes of the two systems.

\section{A. Selecting Indexes for Principle Opponent Analysis Method}

In order to correctly estimate status of population structure and level of regional economic developmentt, with systematic, dynamic, scientific, operational, comprehensive, data available
TABLE 1 INDEXES OF POPULATION STRUCTURE AND ECONOMIC DEVELOPMENTT

\begin{tabular}{|c|c|c|}
\hline Object & Factors & Variables \\
\hline \multirow{6}{*}{ 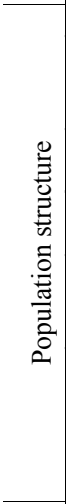 } & Sex & Sex Ratio $X_{1}$, Sex Ratio in born $X_{2}$ \\
\hline & Age & $\begin{array}{l}\text { Children Dependency Ratio } \mathrm{X}_{3} \text {, Dependency Ratio of } \\
\text { Children over Aged } 65^{+} \mathrm{X}_{4} \text {, Economically Active } \\
\text { Population over Aged } 15-64 \mathrm{X}_{5}\end{array}$ \\
\hline & $\begin{array}{l}\text { Urban \& } \\
\text { Rural }\end{array}$ & $\begin{array}{l}\text { Urban population over the rural } \mathrm{X}_{6} \text {, Urban employed } \\
\text { population over the rural } \mathrm{X}_{7}\end{array}$ \\
\hline & $\begin{array}{l}\text { Employ } \\
\text { Units }\end{array}$ & $\begin{array}{l}\text { Employee ratio in State-owned Units } \mathrm{X}_{8} \text {, Employee ratio } \\
\text { in } \mathrm{X}_{9}\end{array}$ \\
\hline & Industry & $\begin{array}{l}\text { Employee ratio in Primary Industry } \mathrm{X}_{10} \text {, Employee ratio in } \\
\text { Secondary Industry } \mathrm{X}_{11} \text {, Employee ratio in Tertiary } \\
\text { Industry } \mathrm{X}_{12}\end{array}$ \\
\hline & $\begin{array}{l}\text { Educational } \\
\text { Attainment }\end{array}$ & $\begin{array}{l}\text { High education graduators over total population X13, } \\
\text { Senior school graduates over total population } X_{14} \text {, Junior } \\
\text { school graduators over total population } X_{15} \text {, Vocational } \\
\text { education graduates over total population } X_{16} \text {, Elementary } \\
\text { school graduates over total population } X_{17}\end{array}$ \\
\hline \multirow{7}{*}{ 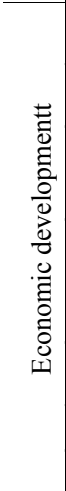 } & $\begin{array}{l}\text { Economy } \\
\text { quantity }\end{array}$ & GDP $Y_{1}$, GDP per capita $Y_{2}$, growth rate of GDP $Y_{3}$ \\
\hline & $\begin{array}{l}\text { Economy } \\
\text { structure }\end{array}$ & $\begin{array}{l}\text { Ratio of primary industry } Y_{4} \text {, Ratio of secondary industry } \\
Y_{5} \text {, Ratio of tertiary industry } Y_{6}\end{array}$ \\
\hline & $\begin{array}{l}\text { Primary } \\
\text { distribution }\end{array}$ & $\begin{array}{l}\text { Total amount of employee wage amount } \mathrm{Y}_{7}, \text { Geordie } \\
\text { coefficient } \mathrm{Y}_{8} \text {, dominated income of urban inhabitant } \mathrm{Y}_{9} \text {, } \\
\text { average net income of rural inhabitant } \mathrm{Y}_{10}\end{array}$ \\
\hline & $\begin{array}{c}\text { Inhabitant } \\
\text { consumption }\end{array}$ & $\begin{array}{l}\text { Consumption payout per person } Y_{11} \text {, Engel coefficient of } \\
\text { urban inhabitant } Y_{12} \text {, Engel coefficient of rural inhabitant } \\
Y_{13} \text {, consumption ratio of urban to rural } Y_{14} \text {, consumption } \\
\text { price index } Y_{15} \text {, commodity retail price index }\end{array}$ \\
\hline & Investment & $\begin{array}{l}\text { Investment in educational outlay } \mathrm{Y}_{17} \text {, investment in } \\
\text { capital assets } \mathrm{Y}_{18} \text {, finance investment in agriculture } \mathrm{Y}_{19}\end{array}$ \\
\hline & Income & Increase rate of finance income $Y_{20}$, foreign exchange $Y_{21}$ \\
\hline & Energy & Energy consumption amount $\mathrm{Y}_{22}$ \\
\hline
\end{tabular}
principle and on base of frequency statistic, theory analysis and experts consultation, we select structure of sex, age, educational attainment, urban and rural and employed units, industry be factors of population structure including 17 variables. Select economy level, economy structure, primary distribution, inhabitant consumption, investments, income and energy consumption be factors of economic developmentt including 22 variables as shown in table1.

\section{B. Integrated Indexes of the Population Structure and Economic Development}

1) Data matrix of sub systems. Let P and T be separately sub systems of population structure \& economic development select original data of $n$ samples of both sub systems to build data matrix $\mathrm{P}$ and $\mathrm{T}$ as follows :

Wherein, subscript $\mathrm{a}, \mathrm{b}$ are variable numbers for sub-system 


$$
P=\left|\begin{array}{l}
P_{11} P_{12} \ldots P_{1 n} \\
P_{21} P_{22} \ldots P_{2 n} \\
\ldots \ldots \ldots \ldots \ldots . . \ldots \\
P_{a 1} P_{a 2} \ldots P_{a n}
\end{array}\right|, \quad T=\left|\begin{array}{l}
T_{11} T_{12} \ldots T_{1 n} \\
T_{21} T_{22} \ldots T_{2 n} \\
\ldots \ldots \ldots \ldots \ldots . . \\
T_{b 1} T_{b 2} \ldots T_{b n}
\end{array}\right|
$$

$\mathrm{P}$ and $\mathrm{T}$, here $\mathrm{a}=17, \mathrm{~b}=22$; Subscript $\mathrm{n}$ is the $\mathrm{n}^{\text {th }}$ year sample. Select original data of 12 years of 1997-2008 according to table 1 from China population and employment statistic yearbook 2009 and China statistic yearbook 2009, n=12.

2) Standardization of original data. In order to remove the dimension affect of different variables, there is a usual method to standardize variables. According to the characteristic of main component method and the selected indexes system, here a linearity z-score method is used to standardize data to let the standardized data be linear relationship with the original data.

3) Integration index of sub systems. Using principal component analysis method, calculate $\mathrm{P}(\mathrm{x})$ as integration index of population structure system and $\mathrm{T}(\mathrm{y})$ as index of economic developmentt system. Herein,

Index of population structure: $P(x)=\sum_{i=1}^{p} \alpha_{i} x_{i}$

Index of economic developmentt: $T(y)=\sum_{j=1}^{t} \beta_{j} y_{j}$

$\alpha \mathrm{i}, \beta \mathrm{j}$ are weights of different factors separately for population structure and economic developmentt, expressed by ratio of variance contribution of each main component to total variable contribution.

\section{Harmony Level and Stage Mining of Population Structure and economic developmentt}

Harmony level of population structure and economic developmentt is the status that the two systems are promoting each other and developing in a suitable proportion. As a quantity index, harmony level and stage between two sub systems is suitable to be measured by coordination degree. That is to say, the bigger correlation between two systems is, the better positively development of them. So, we select correlation analytical method to found a coordination degree model (3) for harmony level mining between population structure and economic developmentt.

$$
C=\frac{\sum_{i=1}^{n}\left[p(x)_{i}-\overline{p(x)}\right] \cdot\left[t(y)_{i}-\overline{t(y)}\right]}{\sqrt{\sum_{i=1}^{n}\left[p(x)_{i}-\overline{p(x)}\right]^{2}} \sqrt{\sum_{i=1}^{n}\left[t(y)_{i}-\overline{t(y)}\right]^{2}}}
$$

Wherein: $\mathrm{C}$ is coordination, $-1 \leq \mathrm{C} \leq 1, \mathrm{p}(\mathrm{x}) \mathrm{i}, \mathrm{t}(\mathrm{y}) \mathrm{i}$ separately are development level scores of population structure and economy in the year $\mathrm{i}, \overline{p(x)}$ and $\overline{t(y)}$ are separately mean development level scores of population structure and economic development during the $i$ years, $i \geq 3$.

Due to characteristic of population structure, the optimizing

\begin{tabular}{|c|c|c|c|c|c|c|c|}
\hline $\begin{array}{c}\text { Coordi- } \\
\text { nation }\end{array}$ & $\begin{array}{c}-1.000 \\
\sim-0.958\end{array}$ & $\begin{array}{c}-0.958 \\
\sim-0.934\end{array}$ & $\begin{array}{c}-0.934 \\
\sim-0.805\end{array}$ & $\begin{array}{l}-0.805 \\
\sim 0.805\end{array}$ & $\begin{array}{c}0.805 \\
-0.935\end{array}$ & $\begin{array}{c}0.934 \\
\sim 0.958\end{array}$ & $\begin{array}{c}0.958 \\
\sim 1.000\end{array}$ \\
\hline $\begin{array}{c}\text { Harmony } \\
\text { Stage }\end{array}$ & $\begin{array}{c}\text { Severity } \\
\text { Mala- } \\
\text { justment }\end{array}$ & $\begin{array}{l}\text { Mid } \\
\text { Mala- } \\
\text { ustment }\end{array}$ & $\begin{array}{l}\text { A little } \\
\text { Mala- } \\
\text { justment }\end{array}$ & $\begin{array}{l}\text { Close } \\
\text { Mala- } \\
\text { ustment }\end{array}$ & $\begin{array}{c}\text { A little } \\
\text { Harmony }\end{array}$ & $\begin{array}{c}\text { Mid- } \\
\text { harmony }\end{array}$ & $\begin{array}{l}\text { High } \\
\text { hamony }\end{array}$ \\
\hline
\end{tabular}

TABLE 2 HARMONY STAGE BY COORDINATION degree (C) speed of population structure is slower than that of economic development. The actual relationship is difficult to observe in short period. We select sliding period of 5 years to study the harmony change trend between population structure and regional economic development, which tallies not only with the inherence relationship but also with the national and regional "5-years" plan.

\section{E. Harmony Stage by Coordination Degree}

With reference of some research achievements ${ }^{[9]-[11]}$, we classify the stage of coordination degree with critical value of sample correlation coefficient test as harmony between population structure and economic development as table 2 . Wherein $0.805,0.934$ and 0.958 are separately the value of $\mathrm{C}_{0.1}, \mathrm{C}_{0.02}$ and $\mathrm{C}_{0.01}$ (Table data) when samples 5 . The value is getting smaller with the increase of the sample getting bigger at unified confidence interval. Set the critical value of 5 samples as partition criterion. When the sample is more than 5, it is remarkable if only value $C$ is bigger than the critical value of 5 samples at unified confidence level.

\section{III . EVALUATION OF POPULATION STRUCTURE AND}

\section{ECONOMIC DEVELOPMENT}

\section{A. Principal Component Analysis on Population Structure and economic developmentt}

The contribution ratio and accumulative contribution ratio of principle components of population structure and economic developmentt can be calculated as shown in table 3 .

With principal components data in (1) and (2), we get the integrated index of population structure $\mathrm{P}(\mathrm{x})_{\mathrm{i}}$ and economic development $\mathrm{T}(\mathrm{y})_{\mathrm{i}}$ by (4) and (5) every year in 1997-2008.

$$
\begin{aligned}
& \mathrm{P}(\mathrm{x})_{\mathrm{i}}=0.8515 \mathrm{P}_{1}+0.1485 \mathrm{P}_{2} \\
& \mathrm{~T}(\mathrm{y})_{\mathrm{i}}=0.8280 \mathrm{~T}_{1}+0.1720 \mathrm{~T}_{2}
\end{aligned}
$$

According to property of the principle component analysis, the score value of population structure $\mathrm{P}(\mathrm{x})$ is numerically equal to that of economic development $\mathrm{T}(\mathrm{y})$. Each $\mathrm{P}(\mathrm{x})$ is equivalence to each $\mathrm{T}(\mathrm{y})$. So we can draw indexes value of $\mathrm{P}(\mathrm{x})$ and $\mathrm{T}(\mathrm{y})$ since 1997 with (4) and (5) in the same coordinate as shown in Fig.1.

\section{B. Analysis on Integration Index of Population Structure and Economic developmentt}

Using principal component analysis method, we get the integration index of some system development during some years. So the single index weight of every year in integration index is the reflection of relatively level instead of absolute

TABLE 3 PRINCIPAL COMPONENT OF POPULATION STRUCTURE AND ECONOMIC DEVELOPMENT

\begin{tabular}{ccccccc}
\hline $\begin{array}{c}\text { Population } \\
\text { structure }\end{array}$ & $\mathrm{P}_{1}$ & $\mathrm{P}_{2}$ & $\begin{array}{c}\text { Economic } \\
\text { development }\end{array}$ & $\mathrm{T}_{1}$ & $\mathrm{~T}_{2}$ \\
\hline Eigenvalue & 13.777 & 2.403 & Eigenvalue & 16.715 & 3.473 \\
$\begin{array}{c}\text { Contribution ratio } \\
(\%)\end{array}$ & 76.536 & 13.349 & $\begin{array}{c}\text { Contribution ratio } \\
(\%)\end{array}$ & 75.977 & 15.786 \\
$\begin{array}{c}\text { Accumulative } \\
\text { contribution ratio } \\
(\%)\end{array}$ & 76.536 & 89.886 & $\begin{array}{c}\text { Accumulative } \\
\text { contribution ratio } \\
(\%)\end{array}$ & 75.977 & 91.763 \\
\hline
\end{tabular}




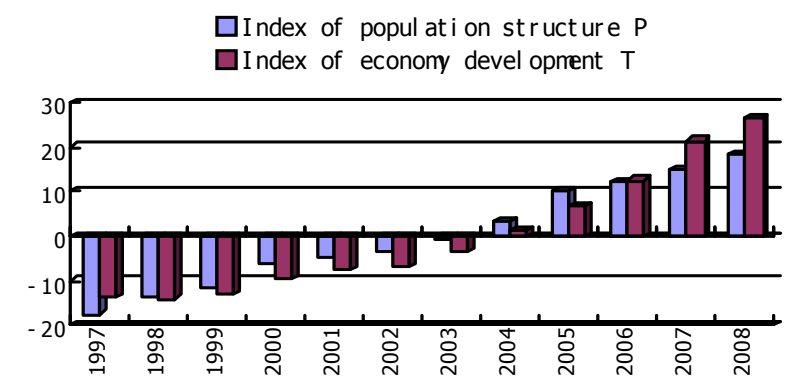

FIGURE 1 INTEGRATION INDEX OF POPULATION STRUCTURE AND ECONOMIC DEVELOPMENTT

level in the whole period. We can get the conclusion from figure 2 as follows.

1 ) Same upside development of two sub systems. Both integration indexes of population structure and economic developmentt are getting increased upwards during 1997-2008. That is to say, the population structure and economic developmentt are both in the way to advanced status.

2 ) Different optimizing speeds of two sub systems. Both the integration indexes in 1997-2003 are lower than average value of population structure and economic developmentt in the twelve years of 1997-2008. The population structure is optimizing faster than economic development before 2003 but slower than economic development since 2004. Both the population structure and economic development are in the most optimized level in 2008 during 1997-2008.

3 ) Different development span of two sub systems. The integration index of population structure is increasing from -17.4 in 1997 to 18.05 in 2008 with increase span 35.45, which is smaller that 39.95 , the increase span from -13.5 in 1997 to 26.44 in 2008 of economic development during the same period. With the time going, the population structure is lag behind the economic development. It is necessary to optimize population structure to harmony with economic developmentt in future China.

\section{HARMONY MINING IN POPULATION STRUCTURE AND}

\section{ECONOMIC DEVELOPMENT}

\section{A. Knowledge Mining of Harmony Stage and Trend}

We can get integration indexes $\mathrm{P}$ and $\mathrm{T}$ every 5 sliding year, figure out the harmony trend of population structure and economic development since 1997. The harmony level is

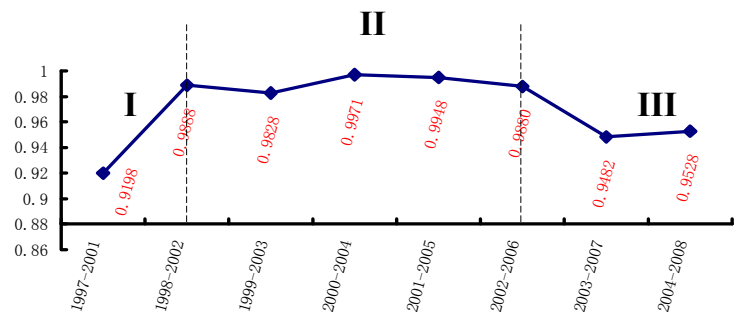

FIGURE 2 HARMONY TREND OF POPULATION STRUCTURE AND ECONOMIC DEVELOPMENTT shown as economic development since 1997. The harmony is shown as a curve in fig 2 according to the above calculation.

\section{B. Conclusion of Harmony Stage and Trend}

The curve is starting from 0.9198, the lowest in 1997-2002, first five-years we'd studied. Then the harmony is fluctuating from the highest 0.9888 to the lowest 0.9288 in the $2^{\text {nd }}, 3^{\text {rd }}, 4^{\text {th }}$, $5^{\text {th }}$ and $6^{\text {th }}$ five-years. Finally the harmony is going down to $0.9482-0.9628$ in the $7^{\text {th }}$ and $8^{\text {th }}$ five years. All the 8 five-years harmony trend is 3 grading with reference to table 2. Stage I, the population structure is a little maladjustment harmony with economic development during 1997-2002, then the population structure is going from lower harmony to highest harmony economic development during 1998-2003. Stage II, the population structure is going high harmony with economic development during $2^{\text {nd }}, 3^{\text {rd }}, 4^{\text {th }}, 5^{\text {th }}$ and $6^{\text {th }}$ five-years 1998-2006. Stage III, the population structure is going mid-harmony with economic development during $7^{\text {th }}$ and $8^{\text {th }}$ five-years 2003-2007 and 2004-2008.

\section{Knowledge Mining in Harmony Stage}

1) Stage I, a little maladjustment harmony to high harmony stage. The population structure in China was optimizing slowly before the reform of state-owned enterprises in 1997. The employee ratio in tertiary industry was only $27 \%$ and less. China was propelling transition in mode of economic growth since 1997: from extensive development to intensive development, from the traditional pursuing economy increase speed and economy quantity expansion to intensive economic development mode. A large amount of medium-sized state-owned enterprise implemented reform by three-year battle against poverty and difficulty. A lot of workers were laid off but reemployed. The result testified that employment structure was optimizing, the tertiary industry personnel were increasing, the overall productivity was rising, population structure was more and more harmony with the quick development of economy in China.

2) Stage II, high harmony stage. On one hand, China's accession to the WTO in 2001 was chance and opportunity for many private enterprises' rapid development. A lot of floating population found jobs in private enterprises. The population industry structure was upgrading. On the other hand, the issues of agriculture, farmer and rural area in China have been substantiality improved since 21 st century, numerous policies were put in place to nurture agriculture, the life of farmers improved and the development of rural areas speeded. The central government regarded these issues the most important of all the important works for the Party in the 2004 Central Economic Work Conference. Economic development put forward simultaneously the optimization of population structure. The population structure and economic development were in high harmony stage.

3) Stage III, mid-harmony stage and trend. The population structure was optimizing slower than economic development was since 2007 (Fig1). The population structure and economic development was in stage of mid harmony (table 2) in $7^{\text {th }}$ and $8^{\text {th }}$ five-years with coordination degree smaller than 0.958 in $2003-2007$ and 2004-2008. We come to the conclusion that economic development hasn't driven population structure to 


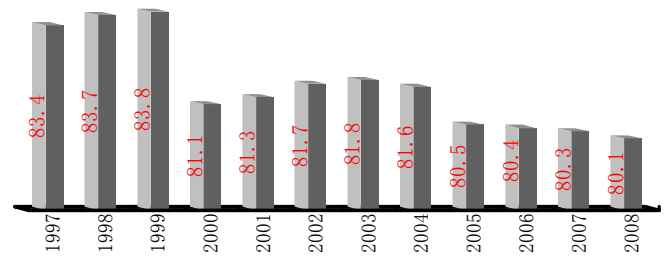

FIGURE 3 RATIO OF ECONOMICALLY ACTIVE POPULATION IN 1997-2008

optimize in recent years to a height degree because of the flowing reasons.

Firstly, the old population ratio and the old dependency ratio have been increasing year by year. Ratio of the old to the children has been bigger than 0.4 since 2006. China is going slowly on the way to an old society. The population age structure is optimizing slower and slower.

Secondly, economy is developing with a large need of amount of persons with abilities. But economically active population ratio in China has being smaller and smaller as shown in fig 4. Nearly $20 \%$ labor force population are unemployed (including campus students) because of voluntary unemployment and involuntary unemployment. The demand and supply of labor force population is structural imbalance, the population structure is mid-harmony with economic development.

4) Conclusion of harmony stage and trend. Seen from the analysis of harmony stage and trend, we can come to the conclusion that the optimization of population structure is very important for national development, is critical for the transition of economic development pattern. Optimizing population structure is necessary for economic development, is the available way to the ultimate goal of transition of the development pattern. Both systems should promote and drive each other for more harmony development and optimization.

\section{SUGGESTIONS ON POPULATION STRUCTURE TO}

\section{HARMONIZE WITH ECONOMIC DEVELOPMENT}

\section{A. Startup Science and Technology Plan to Optimize Population Quality Structure}

The world is entering into a new phase of innovation density and industrial rejuvenation in global. New technology revolution is coming with characteristic of green, intelligent and sustainable development. China should actively start to enable national strategy of technology talent innovation, optimize talent supply structure, take the strategic heights in economy, science and technology by scientific and technological breakthroughs and innovation, promote the economic structure adjustment and population quality structure improve, make technology talent and new strategic industry be new economic engine in future China.

\section{B. Increase Education Investment to Optimize Population Education Structure}

With further transition of economic development pattern, some lower-end foreign trade processing enterprises in industry division chain will gradually lose competitiveness. They are gradually transforming themselves from extensive development into intensive development, from the need for general labors to those high-quality talents. We should greatly increase education investment, extend population education span, cultivate plenty of comprehensive talents for transition of economic development pattern.

\section{Policy Guidance to Optimize Sex and Age Structure}

Propriety increase of baby population every year can contribute to counteract the side-effect because of sustaining population aging in China. Propagandize conception of the equality of men and women, sparkplug scientific civilization and progressive view for marrying and bearing. Do best to ensure that the female's access to education, employment, medical, old-age care housing and etc..

\section{Jobs Creation to Optimize Entirely Employment Structure}

Formulate labor and employment policies based on China's urban and rural employment situation, multi-channel improve the workforce and labor rates. First, improve labor efficiency, moderate labor intensity, shorten labors working time, let the employee have more leisure time and more respectable life. Second, practice flex-time system to attract some personnel for flexible working rhythm; Thirdly, establish consolidated labor market in urban and rural, form talent storage pools for kinds of supply and demand adjustment. Fourth, moderately extend fertility vacations for gestational age women, encourage women employ themselves in housework. Fifth, flexible exploit older talents to retire voluntary earlier or latter, reasonable exploit the sunset human resources advantages.

\section{REFERENCE}

[1] Development Research Center of the State Council. Objectives and strategy of accelerating transition of economic development mode. Theory Journal, 2010.5 pp 41-45

[2] Huang Taiyan. Connotation and realization system of transition of economic development mode. Seeking Truth, 2007,18. pp 6-8.

[3] Si Guang nan. Analysis on coordination of population structure and economic development. Statistic and Decision. 2008 (4) pp.48-50

[4] Su Fei, Zhang Pingyu. Analysis on the coordinated development of population structure and economic developmentt in Liaoning province. system science and comprehensive studies in agriculture. 2010.2. pp107-111.

[5] Hu Jintao. Hold High the Great Banner of Socialism with Chinese Characteristics and Strive for New Victories in Building a Moderately Prosperous Society in all. Report to the Seventeenth National Congress of the Communist Party of China, 2007.10.

[6] Bi Qige, BaoYin, Li Beisui. Coupling association analysis on population structure and regional economy in Inner Mongolia. Geographical research, 2007, 26 (5).pp 995-1004.

[7] National Bureau of Statistic of China. China population and employment statistic yearbook. 2009.

[8] Du JingJing. Theory study on national and international pattern transition of economic development Policy Outlook, 2007. pp. 35-36.

[9] Lihe, Zhang Pingyu, LiuWenxin. Evaluation of coordination between environment and economy in Liaoning Province since 1990.Geography science,2007, 27 (4).pp.486-492.

[10] Liao Zhongbin. Fix quantity evaluation and its classification for harmony development of environment and economy_take cities group in Pearl River Delta as samples.Guangzhou environment science. 1996.11 (1). pp12-16. 